\title{
Effect of Selenium and Foliar Application with Organic Manure Extract on Productivity and Quality of Wheat (Triticum aestivum L.) under New Valley Conditions Shoman, H. A. and A. M. Bughdady \\ Plant Production Dept., Desert Research Center (DRC), El-Matariya, Cairo, Egypt.
}

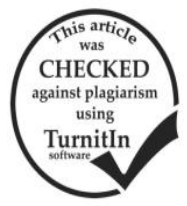

\begin{abstract}
Two field experiments were conducted at EL-Kharga Oasis, Research Station, Desert Research Center (D.R.C.), New Valley Governorate, South Western, Egypt, during two winter growing seasons of 2015/2016 and 2016/2017 to study the effect of poultry manure extract (PME) as a foliar application (1, 2, 3 and $4 \mathrm{~m}^{3} /$ fed.) compared with control and soaking grains in

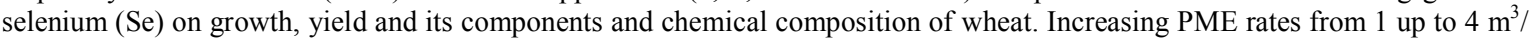
fed increased significantly all characters under study growth, yield and its components and chemical composition except \% selenium compared to zero PME in both seasons. The differences between the two levels 3 and $4 \mathrm{~m}^{3} /$ fed. of PME were not significantly for plant length $(\mathrm{cm})$, no. of tillers/ plant, no. of leaves/ plant, plant fresh weight, plant dry weight and all yield and its components in both seasons. The highest values of growth parameters, yield and its components were obtained by spraying of wheat plants with $3 \mathrm{~m}^{3} \mathrm{PME} /$ fed.in both growing seasons, while, chemical composition were obtained by $4 \mathrm{~m}^{3} \mathrm{PME} / \mathrm{fed}$.in both growing seasons. Increasing Se rates by soaking grains from 5.0 up to $10 \mathrm{mg} \mathrm{Se} / 1$, increased all parameters under studied except, number of leaves/ plant and flag specific leaf weight F.S.L.W. $\mathrm{mg} / \mathrm{cm}^{2}$, spike length $(\mathrm{cm})$ and number of spikelets/ spike and total carbohydrates \% compared to zero selenium in both seasons. All concentrations of Se percentage of all chemical composition were significantly increased in both seasons. However proline were significantly decreased compared with the control in both seasons. The highest values of these parameters were obtained by soaking grains with $10 \mathrm{mg} \mathrm{Se} / 1$ while, the differences between this level and the high level $20 \mathrm{mg} \mathrm{Se} / 1$ were don't significant in both seasons. Furthermore, the results showed that the interaction between PME foliar application and grains soaking with Se rates had a significant effect on all parameters studied in both seasons, except no. of leaves/ plant, flag specific leaf weight $\mathrm{mg} / \mathrm{cm}^{2}$ and grains and \% potassium were insignificant in the two growing seasons. The maximum increments for growth parameters, yield, its components and chemical parameters were obtained by spraying wheat plants by $3 \mathrm{~m}^{3} \mathrm{PME} /$ feddan and grains soaking by $10 \mathrm{mg} \mathrm{Se} / 1$ in both seasons compared with the control except, leaves content of proline had the opposite trend of the other parameters. It could be concluded that grains soaking by Se (10 mg Se/ 1) and foliar spraying of PME at $3 \mathrm{~m}^{3} /$ fed. At every 15 days after sowing in most cases led to increase wheat productivity under New Valley conditions.
\end{abstract}

Keywords: Wheat, foliar spray poultry manure, selenium, organic, growth, yield, chemical composition and selenium content in wheat grains.

\section{INTRODUCTION}

Wheat is one of the most important sources of nutrition in Egypt. Egyptian population depends mainly on baladi bread as a source of food meals being considered relatively cheap compared to other alternative sources such as rice. Despite the increase of wheat production from about 2.5 million Feddan in (2000) to about 3.5 million Feddan in 2017, but its production is not sufficient to cover consumer needs of wheat. Total annual production of Egyptian wheat had reached about 9.5 million tons in (2017), while the consumption about 19.7 million tons, with wheat gap about 48\%, FAO 2017. There are promising newly reclaimed lands in Egypt. In this respect, one of the most suitable locations is New Valley region with its Oases, which represents large land resources and a good hope for agriculture expansion, which located at the Western Desert of Egypt. It represents 38 \% (376000.51 $\mathrm{km}^{2}$ ) of the total area of Egypt and has about 3.5 million feddan available to cultivation.

In such regions, wheat cultivation faces many obstacles, the most important: 1- low efficiency of the productivity of these lands as a result of their poverty in the content of organic matter resulting from the continued demolition due to high temperature in addition to alkalinity of soil and the rule of calcium ions. In such cases, soil defects can be overcome by using organic fertilizers. The most modern methods can be followed in these conditions is application the organic fertilizers extract as a spray on plants because it's a very effective method compared to its cost as well as, being a safe method away from environmental problems that caused by excessive use of chemical fertilizers. In this respect, Moussa et. al., 2006 reported that used organic manure extract as foliar spraying allowed nutrients to be absorbed by the plants directly through stomata on their leaf surfaces. Therefore, using liquid organic fertilizers instead of solid organic application to the soil may be the best use of technology to improve crop productivity and crop heath Martinez et. al., 2016.2- Climate changes that cause exposure of plants to heat stress whereas, wheat plants are very sensitive to high temperature Slafer and Satorre 1999.

Heat stress can cause a loss of membrane integrity, damage to primary photosynth eticprocesses, and changes in lipid composition, and protein denaturation Wahid et. al., 2007 and are break the balance between Reactive Oxygen Species (ROS) production and antioxidant defense, causing accumulation of ROS which resulted in the growth inhibition, the breakdown of lipid membrane, and reduction in photosynthetic parameters. Whereas, You et. al., 2009 indicated that a rise in temperature of just $1^{\circ} \mathrm{C}$ in wheat during the growing season reduces wheat yields by about 3-10\%. During this period, heat stress shortens the growth cycle and forces premature ripening, reduces the number of grains per spike, lowers grain weight, and ultimately results in grain yield and quality deterioration Din et. al., 2010.

Selenium (Se) is an important trace element for plants, which also increased plant tolerance to stressful environment Yao et. al., 2009. The beneficial effect of Se on plant stress tolerance was attributed principally to its antioxidant effects Yao et al., 2009. Besides, it was reported to increase chlorophyll content Yao et. al., 2013 
as well as effective quantum yield of photosystem II (PSII) and stomatal conductance Tadina et al., 2007. Plant water relations were also reported to be positively affected by Se using manifested mainly by higher relative water content Teimouri et al., 2013.Se acts as antioxidant and may be beneficial to the overall growth and metabolism in wheat plants Hartikainen et. al., 2000.Soaking of plant grains by selenium is an easy, low-cost, low-risk, and effective approach to improve plant tolerance under stressful environments Wahid and Shabbir2005. It is a controlled hydration process that promotes metabolic activities before radical protrusion and enhance germination, emergence, growth, and grain yield of wheat Sivritepe et al., 2005. It is well documented that high soil $\mathrm{pH}$, low organic matter content status adversely affect Se uptake in plants Luoma et al., 1995, so Se seed treatment can be an effective technique not only to improve the Se concentration in food crops but can also beneficial in alleviating the drastic effects of heat stress and drought Chen and Sung 2001. Therefore, the objectives of this study to maximizing productivity of wheat under arid regions by using poultry manure extract and soaking of grains wheat by selenium as antioxidant to alleviating the adverse effects of heat stress under New Valley conditions.

\section{MATERIALS AND METHODS}

Two field experiments were carried out at Agricultural Experiment Station EL-Kharga Oasis, (DRC) New Valley Governorate. Experimental sites geographical coordinate is between longitudes $28^{\circ} 48$ and $29^{\circ} 21$ and 25 - $44 \mathrm{~N}$ ) and about 1000 meters above sea level. The research lied was located in a semi arid region were the summer is hot and dry the winter is 3 cool. During two successive winter growing seasons of 2015/2016 and $2016 / 2017$, to study the effect of organic manure extract as a foliar application and soaking of grains wheat by selenium (Se) on growth characters, yield and its components and grains chemical composition of wheat. Soil samples collected before cultivation and analyzed for physical and chemical properties analysis whereas, Soil $\mathrm{pH}$ of experimental site was found to be vary from 9.14 to 9.05 while Ec- 636 to $627 \mathrm{ppm}$, organic matter 0.50 to $0.57 \%$, available nitrogen 61 to $64 \mathrm{ppm}$, available phosphorus 0.52 to $0.55 \mathrm{ppm}$, available potassium 33 to $36 \mathrm{ppm}$ and available sulphur 2.27 to 3.11 in the first and second seasons respectively. Soil samples analyzed was found to be of sandy clay loam texture.

Analysis of poultry manure was as followed: $\mathrm{C} / \mathrm{N}$ ratio was 9.7 and $9.5, \mathrm{~N} \%$ was 1.89 and $1.96, \mathrm{P}_{2} \mathrm{O}_{5} \%$ was 1.63 and $1.58, \mathrm{~K}_{2} \mathrm{O} \%$ was 1.22 and $1.29, \mathrm{Ca} \% 0.93$ and $0.90, \mathrm{Mg}$ was 0.48 and $0.51, \mathrm{Fe}$ was 947 and $961 \mathrm{ppm}, \mathrm{Zn}$ was 152 and $167 \mathrm{ppm}, \mathrm{Cu}$ was 37 and $39 \mathrm{ppm}$ and $\mathrm{Mn}$ 228 and 242 ppm in 2015/ 2016 and 2016/ 2017 growing seasons respectively. Cultivar of wheat (Triticum aestivum $L)$ cv. Sids 12 was used which obtained from the Agriculture research center ,Giza, Egypt. The grins $(500 \mathrm{~g} / \mathrm{l})$ were pretreated with selenium by soaking for $12 \mathrm{hr}$. as open air at 0.05 .0as sodium selenite. 10 and 20 $\mathrm{mg} / \mathrm{l}$ and metered to organic weight nearly with forced air under shade Sund strom et al., 1987. Five rates (every rate dissolved in $200 \mathrm{~L}$ water/fed.) poultry manure extract used a foliar spring treatments $(0,1,2,3,4 \mathrm{~m} 3 /$ fed.) were applied every 5 day from sowing respectively. While the grain soaking were allocated to sub at design split plot with six replicates which the experiment included 20 treatments which were the combinations between the five rates of poultry manure extract as a foliar application and four levels of selenium as Se solution for soaking wheat grains:

\section{A - Organic manure extract: PME}

Organic manure was used as the form of poultry manure at the rates of $0.0,1,2,3$ and $4 \mathrm{~m}^{3} /$ fed. as foliar application on wheat plants and was done 6 times during growing season, first after one month of planting and then every 15 days. Where, poultry manure was fermented in water by the different rates $0.01 .0,2.0,3.0$ and $4.0 \mathrm{~m}^{3}$ / fed. for seven days and then spraying the extract on the plants every 15 days at the rate of 200 L. Spraying was done 6 times during growing season.

\section{B - Selenium:}

Selenium was applied as sodium selenite $\mathrm{Na}_{2} \mathrm{SeO}_{4}$ by soaking grains of wheat for 12 hour in different levels of selenium $0.0,5.0,10$ and $20 \mathrm{mg} / 1$ then directly sowing after 30 minutes. Which three of them were used for growth determinations and the other three were used for yield and its component, as well as chemical composite at harvest. The growth periods of wheat plants were 135 and 139 days after sowing in 2015/2016 and 2016/2017 growing seasons, respectively. The irrigation system used was developed surface irrigation plot area was. $10.5 \mathrm{~m}^{2}$ consisting of five rows $3.5 \mathrm{~m}$ length and $60 \mathrm{~cm}$ between rows). Each plot contained five ridge, each ridge was $3.5 \mathrm{~m}$ length and $60 \mathrm{~cm}$ in width. The recommended collected practices such as for tillage for growing wheat plots were applied. The preceding summer crop was Peanut in both seasons. First irrigation was applied at 15 days after sowing and then plants were irrigated every 8 days till the dough stage.

At harvest time, ten guarded and tagged plants were selected from the middle of plot for every treatment to determine growth character: plant height $(\mathrm{cm})$, No. of tillers/ plant, No. of leaves/ plant, fresh weight, dry weight /plant, leaf area $\left(\mathrm{cm}^{2}\right)$, specific leaf weight $\mathrm{mg} / \mathrm{cm}^{2}$, total chlorophyll proline after 85 days from sowing, Yield and yield components: number of spikes/ $\mathrm{m}^{2}$, spike length $(\mathrm{cm})$, spikes weight $(\mathrm{g})$, number of spikelet's /spike, number of grains/ spike, 1000-grain weight (g), grain yield (kg /fed.), straw yield (kg/fed.) harvest index (\%) and crop index (\%) and 3- chemical composition of grains wheat: percentages of $\mathrm{N}$ (total nitrogen was determined using modified micro-Kjeldahl method as described by Peach and Tracey 1956. The crude protein content was calculated by multiply by 6.25 to obtain the crude protein percentage.), $\mathrm{P}$, K(potassium content percentage was determined photo-metrically using flame photometer model concerning as described by Johnson and Ulrich 1959. , Se, protein and total carbohydrates \% (total available carbohydrates were extracted according to Smith et. al., 1964 and estimated calorimetrically by phenolsulphuric acid method as described by Montogomery 1961 .

Whereas, flag leaf area $\mathrm{cm}^{2}$ determined by portable leaf area meter model "Li-3000". , total chlorophyll determined in the flag leaf by chlorophyll meter, harvest index (\%) was computed by using the 
formula as followed, HI $(\%)$ = grain yield / biological yield $\mathrm{x} 100$, crop index $(\%)$ was computed by using the formula as followed, CI $(\%)=$ grain yield $/$ straw yield $\mathrm{x}$ 100., phosphorus content percentage determined using the method described by John 1970.

All the obtained data were subjected to the statistically analysis and comparison were done using L.S.D. T test at $5 \%$ level of probability.

\section{RESULTS AND DISCUSSION}

Effect of organic manure extract (poultry manure extract, PME):

Growth characters:

Available results in Table (1) revealed that the effect of poultry manure extract (PME) on some growth characters studied i.e. plant height $\mathrm{cm}$, no. of tillers/ plant, no. of leaves/ plant, plant fresh weight, plant dry weight, flag leaf area $\mathrm{cm}^{2}$, flag specific leaf weight F.S.L.W. mg/ $\mathrm{cm}^{2}$ and total chlorophyll (SPAD) at heading stage (85 days after sowing) were affected significantly by spraying of PME in both seasons. On the other hand, leaves content of proline had the opposite trend of the other parameters, where the highest concentration resulted from the control treatment however, the higher rate of spraying with PME reduced the content of the leaves, therefor the lowest concentration result from the highest rate of PME spraying in both growing seasons. This may be because plants that don't treat by extract suffered from stresses and therefor increases leaves content of proline, these results are correspond with Sujin 2004 and Kishor et al., 2005.

Data showed that applying PME spray levels from zero to $4 \mathrm{~m}^{3}$ / fed.to wheat plants caused an significant increase in all these parameters but the differences between the two levels 3 and $4 \mathrm{~m}^{3} /$ fed. of PME were not significantly for plant length $(\mathrm{cm})$, no. of tillers/ plant, no. of leaves/ plant, plant fresh weight and plant dry weight in the two growing seasons.

Results revealed that foliar application of PME by $4 \mathrm{~m}^{3} /$ fed. is a quite enough to achieve the highest values of the studied parameters under the current experiment. Where, spraying at this level of PME resulted a burning of some plant leaves during heading stage which observed during the growing seasons as a result of the increase rates of spraying but the effect wasn't great. The positive effect of PME treatment on the plant growth is due to that this extract enhanced: development of meristems tissue, number of flower buds, photosynthetic activity, and biosynthesis of chlorophyll, mobilization of photosynthesis, photosynthetic $\mathrm{CO}_{2}$ fixation, cell division and carbohydrate metabolism. These results agreed with those obtained by Gowda et al., 2008 and Martinez et al., 2016.

\section{Yield and its components:}

Data in Table (2) showed that increasing spraying levels of PME from 0.0 (control treatment) to $4 \mathrm{~m}^{3} /$ fed. caused a significant increase in all yield and its components of wheat plants under this study in the both seasons. The highest values of number of spikes $/ \mathrm{m}^{2}$, spike length $(\mathrm{cm})$, spikes weight $(\mathrm{g})$, number of spikelets/ spike, number of grains/ spike,1000-grain weight (g), grain yield $\mathrm{kg} /$ fed., straw yield $\mathrm{kg} /$ fed., harvest index (\%) and crop index (\%) were obtained at $4 \mathrm{~m}^{3} \mathrm{PME} /$ fed. compared with control treatment (spraying with water only), this is fairly true in both seasons but the difference between this level and the lower level $\left(3 \mathrm{~m}^{3} \mathrm{PME} / \mathrm{fed}\right.$.) don't was significant with all studied parameters in both growing seasons.

The increasing percentages of these attribute with using the highest rate of PME at $4 \mathrm{~m}^{3} /$ fed. as comparing with control treatment: number of spikes $/ \mathrm{m}^{2}$ were 16.46 and 14.04; spike height $(\mathrm{cm})$ were 57.81 and 56.56; spikes weight $(\mathrm{g})$ were 58.57 and 58.41 ; number of spikelets/ spike were 18.36 and 20.11; number of grains/ spike were 24.03 and $22.87 ; 1000$-grain weight (g) were 17.05 and 17.93; grain yield $\mathrm{kg} /$ fed. were 53.85 and 56.90; straw yield $\mathrm{kg} /$ fed. were 31.98 and 33.62; harvest Index (\%) were 5.79 and 6.76 and crop index (\%) were 11.69 and 11.73 2015/ 2016 and 2016/ 2017 growing seasons, respectively.

Table 1. Effect of foliar spray poultry manure extract on wheat growth characters 2015/2016 and 2016/ 2017 under New Valley conditions.

\begin{tabular}{|c|c|c|c|c|c|c|c|c|c|}
\hline $\begin{array}{l}\text { Char. } \\
\text { Poultry manure extract } \\
\text { (PME) }\end{array}$ & $\begin{array}{l}\text { Plant } \\
\text { height } \\
(\mathbf{c m})\end{array}$ & $\begin{array}{l}\text { No. of } \\
\text { tillers/ } \\
\text { plant }\end{array}$ & $\begin{array}{c}\text { No. of } \\
\text { leaves/ } \\
\text { plant }\end{array}$ & $\begin{array}{c}\text { Plant } \\
\text { fresh } \\
\text { weight(g) }\end{array}$ & $\begin{array}{c}\text { Plant } \\
\text { dry } \\
\text { weight(g) }\end{array}$ & $\begin{array}{c}\text { Flag } \\
\text { leaf } \\
\operatorname{area}\left(\mathrm{cm}^{2}\right)\end{array}$ & $\begin{array}{l}\text { F.S.L.W. } \\
\left(\mathrm{mg} / \mathrm{cm}^{2}\right)\end{array}$ & $\begin{array}{c}\text { Total } \\
\text { chlorophyll } \\
\text { (SPAD) }\end{array}$ & $\begin{array}{c}\text { Leaves } \\
\text { Proline } \\
\mu \text { mol/ } \\
\text { g FW }\end{array}$ \\
\hline \multicolumn{10}{|c|}{$2015 / 2016$} \\
\hline Without spraying (control) & 73.21 & 2.37 & 16.35 & 26.58 & 5.42 & 15.02 & 7.54 & 38.64 & 5.56 \\
\hline Spraying with $1 \mathrm{~m}^{3} / \mathrm{f}$. & 79.56 & 3.62 & 17.22 & 33.18 & 6.23 & 18.95 & 8.11 & 39.47 & 4.87 \\
\hline Spraying with $2 \mathrm{~m}^{3} / \mathrm{f}$. & 83.28 & 3.97 & 17.75 & 37.21 & 6.71 & 20.05 & 8.87 & 40.00 & 4.52 \\
\hline Spraying with $3 \mathrm{~m}^{3} / \mathrm{f}$. & 86.20 & 4.85 & 18.10 & 40.64 & 7.14 & 21.46 & 9.13 & 42.17 & 3.92 \\
\hline Spraying with $4 \mathrm{~m}^{3} / \mathrm{f}$. & 88.56 & 5.12 & 18.34 & 41.55 & 7.36 & 23.63 & 9.38 & 44.34 & 3.30 \\
\hline LSD at $5 \%$ & 2.65 & 0.33 & 0.28 & 2.17 & 0.25 & 1.03 & 0.21 & 0.38 & 0.29 \\
\hline \multicolumn{10}{|c|}{$2016 / 2017$} \\
\hline Without spraying (control) & 74.35 & 2.41 & 16.94 & 27.10 & 5.68 & 15.10 & 7.86 & 39.52 & 5.94 \\
\hline Spraying with $1 \mathrm{~m}^{3} / \mathrm{f}$. & 79.41 & 3.71 & 17.35 & 34.37 & 6.45 & 19.14 & 8.25 & 40.12 & 4.91 \\
\hline Spraying with $2 \mathrm{~m}^{3} / \mathrm{f}$. & 84.31 & 4.12 & 17.98 & 38.00 & 6.88 & 20.74 & 8.91 & 41.50 & 4.61 \\
\hline Spraying with $3 \mathrm{~m}^{3} / \mathrm{f}$. & 88.27 & 5.20 & 18.72 & 40.74 & 7.76 & 23.36 & 9.62 & 43.80 & 4.13 \\
\hline Spraying with $4 \mathrm{~m}^{3} / \mathrm{f}$. & 90.47 & 5.58 & 19.07 & 42.96 & 7.94 & 25.48 & 10.05 & 44.85 & 3.73 \\
\hline LSD at $5 \%$ & 2.38 & 0.39 & 0.31 & 1.84 & 0.16 & 1.23 & 0.26 & 0.43 & 0.25 \\
\hline
\end{tabular}


Table 2. Effect of foliar spray poultry manure extract on yield and its components in 2015/ 2016 and 2016/ 2017 under New Valley conditions.

\begin{tabular}{|c|c|c|c|c|c|c|c|c|c|c|}
\hline $\begin{array}{l}\text { Char. } \\
\text { PME }\end{array}$ & $\begin{array}{c}\begin{array}{c}\text { No. of } \\
\text { spikes } \\
/ \mathbf{m}^{2}\end{array} \\
\end{array}$ & $\begin{array}{c}\text { Spike } \\
\text { length } \\
\text { (cm) }\end{array}$ & $\begin{array}{c}\text { Spike } \\
\text { weight } \\
\text { (g) }\end{array}$ & $\begin{array}{c}\text { No. of } \\
\text { spikelets } \\
\text { /spike }\end{array}$ & $\begin{array}{l}\text { No. of } \\
\text { grains } \\
\text { /spike } \\
\end{array}$ & $\begin{array}{l}\text { 1000-grain } \\
\text { weight }(\mathrm{g})\end{array}$ & $\begin{array}{c}\text { Grain } \\
\text { yield } \\
\text { (kg/fed.) }\end{array}$ & $\begin{array}{c}\text { Straw } \\
\text { yield } \\
\text { (kg/fed.) }\end{array}$ & $\begin{array}{r}\text { Harvest } \\
\text { index \% }\end{array}$ & $\begin{array}{c}\text { Crop } \\
\text { index \% }\end{array}$ \\
\hline \multicolumn{11}{|c|}{$2015 / 2016$} \\
\hline control & 331.2 & 7.23 & 2.10 & 15.85 & 34.71 & 36.84 & 1337 & 2117 & 38.14 & 60.42 \\
\hline $1 \mathrm{~m}^{3} \mathrm{PME} / \mathrm{f}$. & 352.0 & 9.35 & 2.51 & 16.73 & 37.20 & 12 & 1573 & 2292 & 39.12 & .11 \\
\hline $2 \mathrm{~m}^{3} \mathrm{PME} / \mathrm{f}$. & 365.9 & 10.20 & 2.90 & 17.52 & 39.12 & 40.84 & 1768 & 2501 & 39.62 & 64.85 \\
\hline $3 \mathrm{~m}^{3} \mathrm{PME} / \mathrm{f}$. & 379.1 & 11.23 & 3.21 & 18.54 & 42.63 & 42.50 & 1992 & 2685 & 40.17 & 66.91 \\
\hline $4 \mathrm{~m}^{3} \mathrm{PME} / \mathrm{f}$. & 385.7 & 11.41 & 3.33 & 18.76 & 43.05 & 43.12 & 2057 & 2794 & 40.35 & 67.48 \\
\hline LSD at $5 \%$ & 9.25 & 0.41 & 0.17 & 0.27 & 0.63 & 0.75 & 72 & 116 & 0.23 & 0.65 \\
\hline \multicolumn{11}{|c|}{$2016 / 2017$} \\
\hline control & 342.5 & 7.55 & 2.14 & 16.06 & 36.48 & & 1341 & 2130 & & .79 \\
\hline $1 \mathrm{~m}^{3} \mathrm{PME} / \mathrm{f}$. & 360.1 & 9.46 & 2.64 & 16.86 & 38.84 & 40.25 & 1610 & 2317 & 39.29 & 64.31 \\
\hline $2 \mathrm{~m}^{3} \mathrm{PME} / \mathrm{f}$. & 372.8 & 10.63 & 2.91 & 17.70 & 41.71 & 41.76 & 1842 & 2563 & 40.18 & 65.13 \\
\hline $3 \mathrm{~m}^{3} \mathrm{PME} / \mathrm{f}$. & 383.4 & 11.52 & 3.29 & 18.90 & 43.93 & 43.45 & 2067 & 2775 & 40.84 & 67.42 \\
\hline $4 \mathrm{~m}^{3} \mathrm{PME} / \mathrm{f}$. & 390.6 & 11.82 & 3.39 & 19.29 & 44.82 & 44.19 & 2104 & 2846 & 41.08 & 67.92 \\
\hline LSD at $5 \%$ & 8.41 & 0.35 & 0.20 & 0.42 & 0.92 & 0.80 & 55 & 85 & 0.28 & 0.56 \\
\hline
\end{tabular}

PME: poultry manure extract

Table 3. Effect of foliar spray by poultry manure extract on chemical composition of grains wheat in 2015/ 2016 and 2016/ 2017 under New Valley conditions.

\begin{tabular}{|c|c|c|c|c|c|c|}
\hline $\begin{array}{l}\text { Characters. } \\
\text { PME }\end{array}$ & $\begin{array}{l}\mathbf{N} \\
\%\end{array}$ & $\begin{array}{l}\mathbf{P} \\
\%\end{array}$ & $\begin{array}{l}\mathbf{K} \\
\%\end{array}$ & $\begin{array}{l}\mathrm{Se} \\
\%\end{array}$ & $\begin{array}{l}\text { Protein } \\
\%\end{array}$ & $\begin{array}{c}\text { Total } \\
\text { Carbohyd } \\
\text { rate. } \%\end{array}$ \\
\hline \multicolumn{7}{|c|}{$2015 / 2016$} \\
\hline control & 1.39 & 0.19 & 0.27 & 0.15 & 8.35 & 56.31 \\
\hline $1 \mathrm{~m}^{3} \mathrm{PME} / \mathrm{fed}$. & 1.62 & 0.21 & 0.28 & 0.17 & 10.42 & 59.02 \\
\hline $2 \mathrm{~m}^{3} \mathrm{PME} / \mathrm{fed}$. & 1.92 & 0.23 & 0.29 & 0.22 & 11.78 & 61.15 \\
\hline $3 \mathrm{~m}^{3} \mathrm{PME} / \mathrm{fed}$. & 2.13 & 0.25 & 0.31 & 0.25 & 12.05 & 63.84 \\
\hline $4 \mathrm{~m}^{3} \mathrm{PME} / \mathrm{fed}$. & 2.31 & 0.27 & 0.32 & 0.28 & 13.41 & 65.12 \\
\hline LSD at $5 \%$ & 0.15 & 0.14 & 0.01 & NS & 0.25 & 1.34 \\
\hline \multicolumn{7}{|c|}{$2016 / 2017$} \\
\hline control & 1.40 & 0.19 & 0.28 & 0.16 & 8.40 & 56.87 \\
\hline $1 \mathrm{~m}^{3} \mathrm{PME} / \mathrm{fed}$. & 1.65 & 0.21 & 0.29 & 0.18 & 10.79 & 60.35 \\
\hline $2 \mathrm{~m}^{3} \mathrm{PME} / \mathrm{fed}$. & 1.98 & 0.24 & 0.30 & 0.23 & 12.16 & 62.48 \\
\hline $3 \mathrm{~m}^{3} \mathrm{PME} / \mathrm{fed}$. & 2.17 & 0.26 & 0.31 & 0.26 & 13.07 & 64.00 \\
\hline $4 \mathrm{~m}^{3} \mathrm{PME} / \mathrm{fed}$. & 2.34 & 0.27 & 0.33 & 0.29 & 13.64 & 65.93 \\
\hline LSD at $5 \%$ & 0.14 & 0.14 & 0.03 & NS & 0.39 & 1.21 \\
\hline
\end{tabular}

The good effects of spraying by organic manure at the form poultry manure extract on improve the growth and maximize wheat productivity in the desert regions may be due to that PME are provides plants with necessary nutrients for growth in a soluble an available form, which improves growth and development of plants, in addition to, protecting for diseases and insects as a faraway excessive chemical fertilizers and their negative effects on health and environment. These results are in harmony with those obtained by Niggli 2007; Ibrahim 2008; Zturk et. al., 2012; Younis et. al., 2016; Badr Eldin et. al., 2016.

Chemical composition:

According to the data in Table (3) spraying of PME increased wheat grains content of $\mathrm{N}, \mathrm{P}, \mathrm{K}$, protein and total carbohydrates \% significantly in both seasons but selenium $\%$ don't affected significantly by this treat in both seasons. Whenever increasing the rate of spraying by PME increased concentration of these chemical attribute in grains, this is due to the increase in the rate of spraying by extract of organic manure increases the amount of elements due to the contamination of high concentration of nutrients. These results are supported by the findings of Moussa et. al., 2006; Gowda et. al., 2008 and Younis et. al., 2016.

\section{Effect of soaking wheat grains with selenium:}

\section{Growth characters:}

Data presented in Table (4) indicated that all studied growth characters were affected by soaking of wheat grains with selenium levels except, number of leaves/ plant and flag specific leaf weight F.S.L.W. $\mathrm{mg} / \mathrm{cm}^{2}$ were don't affected by these treatments of selenium whereas, leaves proline content was higher with control treatment then decreased with increasing Se levels. The highest values of these parameters were obtained of soaking wheat grains with 10 $\mathrm{mg} \mathrm{Se} / 1$ of water while, the differences between this level and the high level $20 \mathrm{mg}$ Se/ 1 were don't significant in both seasons. The increasing in studied growth characters may be due to the roles of selenium in enhances growth and metabolism of wheat plants Hartikainen et. al., 2000, alleviating the drastic effects of heat stress and drought Chen and Sung 2001 and promoting plant growth and development Yao et. al., 2009. These results are in the same line with that recorded by Bill 2017.

\section{Yield and its components:}

The data illustrated in Table (5) showed that all studied yield and its components of wheat plants were affected by soaking of wheat grains with selenium levels except, spike length $(\mathrm{cm})$ and number of spikelets/ spike were don't affected significantly by soaking grains with Se. Maximum values of all studied yield and its components were obtained from soaking wheat grains by $10 \mathrm{mg} \mathrm{Se} / 1$ of water compared to control treatments but the differences between this level and the highest of it ( $20 \mathrm{mg} \mathrm{Se} / 1)$ were don't significant with all studied parameters in both seasons.

The increments percentages of these parameters with using this $10 \mathrm{mg} \mathrm{Se} / 1$ as comparing with control treatment: number of spikes/ $\mathrm{m}^{2}$ were 6.54 and 7.88 ; spikes weight $(\mathrm{g})$ were 58.50 and 59.61; number of grains/ spike were 28.00 and 26.92; 1000-grain weight (g) were 23.39 and 25.18; grain yield $\mathrm{kg} /$ fed. were 52.53 and 54.60 ; Straw yield $\mathrm{kg}$ /fed. were 26.99 and 27.01; harvest Index (\%) were 8.81 and 9.08 and crop Index (\%) were 5.32 and 6.18 2015/ 2016 and 2016/ 2017 growing seasons, respectively. These results are in harmony with those obtained by Feng et. al., 2013 and Mona et. al., 2017. 
Table 4. Effect of grains soaking in selenium on wheat growth characters 2015/ 2016 and $2016 / 2017$ seasons .

\begin{tabular}{|c|c|c|c|c|c|c|c|c|c|}
\hline $\begin{array}{l}\text { Char. } \\
\text { Selenium } \\
\text { soaking grains }\end{array}$ & $\begin{array}{c}\text { Plant } \\
\text { height } \\
\text { (cm) }\end{array}$ & $\begin{array}{l}\text { No. of } \\
\text { tillers/ } \\
\text { plant }\end{array}$ & $\begin{array}{c}\text { No. of } \\
\text { leaves/ } \\
\text { plant }\end{array}$ & $\begin{array}{c}\text { Plant } \\
\text { fresh } \\
\text { weight }(g)\end{array}$ & $\begin{array}{l}\text { Plant dry } \\
\text { weight(g) }\end{array}$ & $\begin{array}{c}\text { Flag leaf } \\
\text { area } \\
\left(\mathrm{cm}^{2}\right)\end{array}$ & $\begin{array}{l}\text { F.S.L.W. } \\
\left(\mathrm{mg} / \mathrm{cm}^{2}\right)\end{array}$ & $\begin{array}{c}\text { Total } \\
\text { chlorophy } \\
\text { Il (SPAD) }\end{array}$ & $\begin{array}{c}\text { Leaves } \\
\text { Proline } \\
\mu \text { mol/ } \\
\text { g FW }\end{array}$ \\
\hline \multicolumn{10}{|c|}{$2015 / 2016$} \\
\hline Without selenium (control) & 74.31 & 2.48 & 14.30 & 24.10 & 5.63 & 16.38 & 6.02 & 36.54 & 6.47 \\
\hline Soaking with $5 \mathrm{mg} \mathrm{Se} / \mathrm{L}$ & 80.52 & 3.62 & 14.56 & 30.51 & 6.14 & 19.61 & 6.83 & 38.74 & 5.21 \\
\hline Soaking with $10 \mathrm{mg} \mathrm{Se} / \mathrm{L}$ & 87.36 & 5.33 & 16.52 & 39.64 & 7.84 & 22.74 & 8.02 & 42.10 & 4.52 \\
\hline Soaking with $20 \mathrm{mg} \mathrm{Se} / \mathrm{L}$ & 86.41 & 5.02 & 15.47 & 37.73 & 7.52 & 21.49 & 7.69 & 41.72 & 3.05 \\
\hline LSD at $5 \%$ & 2.64 & 0.30 & NS & 2.40 & 0.35 & 1.30 & NS & 0.41 & 0.68 \\
\hline \multicolumn{10}{|c|}{$2016 / 2017$} \\
\hline Without selenium (control) & 75.02 & 2.64 & 13.85 & 25.38 & 5.74 & 17.15 & 6.15 & 36.97 & 6.85 \\
\hline Soaking with $5 \mathrm{mg} \mathrm{Se} / \mathrm{L}$ & 81.20 & 3.30 & 14.84 & 32.85 & 6.41 & 20.72 & 6.98 & 38.66 & 5.44 \\
\hline Soaking with $10 \mathrm{mg} \mathrm{Se} / \mathrm{L}$ & 88.40 & 5.51 & 17.60 & 39.87 & 8.03 & 22.67 & 8.14 & 42.61 & 4.77 \\
\hline Soaking with $20 \mathrm{mg} \mathrm{Se} / \mathrm{L}$ & 87.51 & 5.11 & 16.63 & 36.94 & 7.82 & 21.40 & 7.82 & 41.95 & 3.41 \\
\hline LSD at $5 \%$ & 1.12 & 0.46 & NS & 2.96 & 0.24 & 1.35 & NS & 0.71 & 0.58 \\
\hline
\end{tabular}

Table 5. Effect of grains soaking in selenium on wheat yield and its components 2015/ 2016 and $2016 / 2017$ in both seasons.

\begin{tabular}{|c|c|c|c|c|c|c|c|c|c|c|}
\hline $\begin{array}{l}\text { Char. } \\
\text { Se }\end{array}$ & $\begin{array}{c}\text { No. of } \\
\text { spikes } \\
/ \mathbf{m}^{2} \\
\end{array}$ & $\begin{array}{l}\text { Spike } \\
\text { length } \\
\text { (cm) }\end{array}$ & $\begin{array}{l}\text { Spike } \\
\text { weight } \\
\text { (g) }\end{array}$ & $\begin{array}{c}\begin{array}{c}\text { No. of } \\
\text { spikelets } \\
\text { /spike }\end{array} \\
\end{array}$ & $\begin{array}{l}\text { No. of } \\
\text { grains } \\
\text { /spike } \\
\end{array}$ & $\begin{array}{c}\begin{array}{c}1000- \\
\text { grain } \\
\text { weight }(\mathrm{g})\end{array} \\
\end{array}$ & $\begin{array}{c}\text { Grain } \\
\text { yield } \\
\text { (kg/fed.) }\end{array}$ & $\begin{array}{c}\text { Straw } \\
\text { yield } \\
\text { (kg/fed.) }\end{array}$ & $\begin{array}{l}\text { Harvest } \\
\text { index \% }\end{array}$ & $\begin{array}{c}\text { Crop } \\
\text { index \% }\end{array}$ \\
\hline \multicolumn{11}{|c|}{$2015 / 2016$} \\
\hline control & 341.4 & 8.02 & 2.00 & 14.51 & 32.10 & 32.62 & 1247 & 1956 & 35.41 & 58.41 \\
\hline $5 \mathrm{mg} \mathrm{Se} / \mathrm{L}$ & 355.0 & 9.14 & 2.37 & 15.82 & 36.55 & 35.94 & 1536 & 1130 & 36.74 & 60.50 \\
\hline $10 \mathrm{mg} \mathrm{Se} / \mathrm{L}$ & 363.5 & 10.96 & 3.17 & 17.86 & 41.09 & 40.25 & 1902 & 2484 & 38.53 & 61.52 \\
\hline $20 \mathrm{mg} \mathrm{Se} / \mathrm{L}$ & 360.2 & 9.83 & 2.97 & 16.9 & 39.61 & 39.71 & 1847 & 2395 & 37.68 & 61.14 \\
\hline LSD at $5 \%$ & 4.50 & NS & 0.24 & NS & 1.52 & 1.20 & 63 & 95 & 0.88 & 0.46 \\
\hline \multicolumn{11}{|c|}{$2016 / 2017$} \\
\hline control & 345.0 & 8.12 & 2.03 & 15.07 & 32.76 & 32.96 & 1260 & 1974 & 36.00 & 59.18 \\
\hline $5 \mathrm{mg} \mathrm{Se} / \mathrm{L}$ & 360.7 & 9.36 & 2.51 & 16.14 & 37.41 & 36.60 & 1554 & 2211 & 37.41 & 61.05 \\
\hline $10 \mathrm{mg} \mathrm{Se} / \mathrm{L}$ & 372.2 & 11 & 3.24 & 18.3 & 41.58 & 41.26 & 1948 & 2525 & 39.27 & 62.84 \\
\hline $20 \mathrm{mg} \mathrm{Se} / \mathrm{L}$ & 368.1 & 10.42 & 2.96 & 17.98 & 39.94 & 40.57 & 1872 & 2465 & 38.84 & 62.18 \\
\hline LSD at $5 \%$ & 4.32 & NS & 0.31 & NS & 1.69 & 1.33 & 82 & 73 & 0.76 & 0.71 \\
\hline
\end{tabular}

Table 6. Effect of grains soaking in selenium on wheat chemical composition in 2015/ 2016 and 2016/ 2017

\begin{tabular}{|c|c|c|c|c|c|c|}
\hline $\begin{array}{l}\text { Char. } \\
\text { Se }\end{array}$ & $\begin{array}{l}\mathbf{N} \\
\%\end{array}$ & $\begin{array}{l}\mathbf{P} \\
\%\end{array}$ & $\begin{array}{l}\mathbf{K} \\
\%\end{array}$ & $\begin{array}{l}\text { Se } \\
\%\end{array}$ & $\begin{array}{c}\text { Protein } \\
\%\end{array}$ & $\begin{array}{l}\text { Total Carboh. } \\
\%\end{array}$ \\
\hline \multicolumn{7}{|c|}{$2015 / 2016$} \\
\hline control & 1.42 & 0.17 & 0.26 & 0.11 & 8.21 & 58.31 \\
\hline $5 \mathrm{mg} \mathrm{Se} / \mathrm{L}$ & 1.75 & 0.19 & 0.27 & 0.35 & 9.95 & 60.34 \\
\hline $10 \mathrm{mg} \mathrm{Se} / \mathrm{L}$ & 2.20 & 0.25 & 0.29 & 0.85 & 12.41 & 63.47 \\
\hline $20 \mathrm{mg} \mathrm{Se} / \mathrm{L}$ & 2.00 & 0.23 & 0.28 & 0.59 & 11.63 & 62.19 \\
\hline LSD at $5 \%$ & 0.22 & 0.26 & 0.09 & 0.02 & 0.66 & NS \\
\hline \multicolumn{7}{|c|}{$2016 / 2017$} \\
\hline control & 1.44 & 0.18 & 0.26 & 0.12 & 8.29 & 58.69 \\
\hline $5 \mathrm{mg} \mathrm{Se} / \mathrm{L}$ & 1.83 & 0.20 & 0.27 & 0.36 & 10.30 & 61.94 \\
\hline $10 \mathrm{mg} \mathrm{Se} / \mathrm{L}$ & 2.25 & 0.25 & 0.29 & 0.87 & 12.88 & 64.01 \\
\hline $20 \mathrm{mg} \mathrm{Se} / \mathrm{L}$ & 2.11 & 0.23 & 0.29 & 0.61 & 11.78 & 63.41 \\
\hline LSD at $5 \%$ & 0.19 & 0.020 & 0.010 & 0.03 & 0.51 & NS \\
\hline
\end{tabular}

\section{Chemical composition:}

Data shown in Table (6) revealed that raising of Se levels from zero to $10 \mathrm{mg} / 1$ as soaking grains increased wheat grains content of $\mathrm{N}, \mathrm{P}, \mathrm{K}, \mathrm{Se}$ and protein $\%$ significantly in both seasons but total carbohydrates \% don't affected significantly by $\mathrm{Se}$ treatments in both seasons. The highest values of grains content of chemical composition studied were produced by using $10 \mathrm{mg} \mathrm{Se} / 1$ in the first and second seasons, respectively. Whereas, the differences between using 10 and $20 \mathrm{mg} \mathrm{Se} / 1$ on grains content of $\mathrm{N}, \mathrm{P}$ and $\mathrm{K} \%$ don't reach to significant level in both seasons. This increasing of chemical attributes percent which due to soaking of grains with Se may be attributed to the role of Se in enhance the tolerance of plants to oxidative stress by increasing of antioxidant enzymes activities and oxidant compound content which leads of sustain plant grow under normal condition therefor, could be able to absorption more of nutrients from the soil thin to grains. Similar results were obtained by Nawaz et. al., 2015 and Mona et al., 2017.

Effect of the interactions between PME and Se: Growth characters:

Effect of the interaction between spraying of PME and soaking wheat grains in levels of Se under New Valley conditions on the some growth characters during 5015/ 2016 and 2016/ 2017 seasons is shown in Table ( $7 \mathrm{a}$ and $\mathrm{b}$ ). The interaction between spraying of PME and soaking wheat grains Se levels had a significant effect on plant height cm, no. of tillers/ plant, plant fresh weight, plant dry weight, flag leaf area $\mathrm{cm}^{2}$, and total chlorophyll (SPAD) at heading stage (85 days 
after sowing) in both seasons, but the interaction between the two studied factors was insignificant in no. of leaves/ plant and flag specific leaf weight F.S.L.W. $\mathrm{mg} / \mathrm{cm}^{2}$ in both seasons. The maximum increments for growth parameters were obtained by spraying wheat plants by $3 \mathrm{~m}^{3} \mathrm{PME} /$ feddan with soaking wheat grains by $10 \mathrm{mg} \mathrm{Se} / 1$ in both seasons. In this respect, the lowest values were achieved by the control treatments for the two factors (PME and Se) in the two seasons.

Table 7a. Effect of the interaction between foliar spray poultry manure extract and grains at heading in 2015/ 2016 season.

\begin{tabular}{|c|c|c|c|c|c|c|c|c|c|c|}
\hline \multicolumn{2}{|c|}{$\begin{array}{l}\text { Char. } \\
\text { PME X Se }\end{array}$} & $\begin{array}{c}\text { Plant } \\
\text { height } \\
\text { (cm) }\end{array}$ & $\begin{array}{c}\text { No. of } \\
\text { tillers/ } \\
\text { plant }\end{array}$ & $\begin{array}{c}\text { No. of } \\
\text { leaves/ } \\
\text { plant }\end{array}$ & $\begin{array}{c}\text { Plant } \\
\text { fresh } \\
\text { weight(g) }\end{array}$ & $\begin{array}{c}\text { Plant } \\
\text { dry } \\
\text { weight(g) }\end{array}$ & $\begin{array}{c}\text { Flag leaf } \\
\text { area } \\
\left(\mathrm{cm}^{2}\right)\end{array}$ & $\begin{array}{l}\text { F.S.L.W. } \\
\left(\mathbf{m g} / \mathbf{c m}^{2}\right)\end{array}$ & $\begin{array}{c}\text { Total } \\
\text { chloroph } \\
\text { yll } \\
\text { (SPAD) }\end{array}$ & $\begin{array}{c}\text { Leaves } \\
\text { Proline } \\
\boldsymbol{\mu} \text { mol/ } \\
\mathrm{g} \mathbf{F W}\end{array}$ \\
\hline \multicolumn{11}{|c|}{$2015 / 2016$} \\
\hline \multirow{4}{*}{ control } & control & 73.76 & 2.43 & 15.46 & 25.34 & 5.53 & 15.70 & 6.78 & 37.59 & 6.02 \\
\hline & $5 \mathrm{mg} \mathrm{Se} / \mathrm{L}$ & 76.87 & 3.00 & 15.33 & 28.55 & 5.78 & 17.32 & 7.19 & 38.69 & 5.39 \\
\hline & $10 \mathrm{mg} \mathrm{Se} / \mathrm{L}$ & 80.29 & 3.85 & 16.44 & 33.11 & 6.63 & 18.88 & 7.78 & 40.37 & 4.31 \\
\hline & $20 \mathrm{mg} \mathrm{Se} / \mathrm{L}$ & 79.81 & 3.74 & 15.91 & 32.16 & 6.47 & 18.26 & 7.62 & 40.18 & 5.04 \\
\hline & control & 76.94 & 3.05 & 15.89 & 28.64 & 5.93 & 17.67 & 7.07 & 38.01 & 5.67 \\
\hline $1 \mathrm{~m}^{3}$ & $5 \mathrm{mg} \mathrm{Se} / \mathrm{L}$ & 80.04 & 3.62 & 15.76 & 31.85 & 6.19 & 19.28 & 7.47 & 39.11 & 5.04 \\
\hline \multirow[t]{3}{*}{ PME/ f. } & $10 \mathrm{mg} \mathrm{Se} / \mathrm{L}$ & 83.46 & 4.48 & 16.87 & 36.41 & 7.04 & 20.85 & 8.07 & 40.79 & 3.96 \\
\hline & $20 \mathrm{mg} \mathrm{Se} / \mathrm{L}$ & 82.99 & 4.39 & 16.35 & 35.46 & 6.88 & 20.22 & 7.90 & 40.60 & 4.70 \\
\hline & control & 78.80 & 3.23 & 16.16 & 30.66 & 6.17 & 18.22 & 7.45 & 38.27 & 5.50 \\
\hline $2 \mathrm{~m}^{3}$ & $5 \mathrm{mg} \mathrm{Se} / \mathrm{L}$ & 81.90 & 3.80 & 16.03 & 33.86 & 6.43 & 19.83 & 7.85 & 39.37 & 4.87 \\
\hline \multirow[t]{3}{*}{ PME/ f. } & $10 \mathrm{mg} \mathrm{Se} / \mathrm{L}$ & 85.32 & 4.65 & 17.14 & 38.43 & 7.28 & 21.40 & 8.45 & 41.05 & 4.79 \\
\hline & $20 \mathrm{mg} \mathrm{Se} / \mathrm{L}$ & 84.85 & 4.56 & 16.61 & 37.47 & 7.12 & 20.77 & 8.28 & 40.86 & 4.52 \\
\hline & control & 81.44 & 3.80 & 16.45 & 32.83 & 6.50 & 20.01 & 7.70 & 40.44 & 5.20 \\
\hline $3 \mathrm{~m}^{3}$ & $5 \mathrm{mg} \mathrm{Se} / \mathrm{L}$ & 84.54 & 4.37 & 16.32 & 36.03 & 6.75 & 21.62 & 8.11 & 41.54 & 4.57 \\
\hline \multirow[t]{3}{*}{ PME/ f. } & $10 \mathrm{mg} \mathrm{Se} / \mathrm{L}$ & 87.96 & 5.23 & 17.43 & 40.61 & 7.60 & 23.19 & 8.70 & 43.22 & 3.49 \\
\hline & $20 \mathrm{mg} \mathrm{Se} / \mathrm{L}$ & 87.49 & 5.12 & 16.91 & 39.64 & 7.44 & 22.56 & 8.54 & 43.03 & 4.22 \\
\hline & control & 81.26 & 3.69 & 16.33 & 32.57 & 6.42 & 19.92 & 7.58 & 40.36 & 4.89 \\
\hline $4 \mathrm{~m}^{3}$ & $5 \mathrm{mg} \mathrm{Se} / \mathrm{L}$ & 83.36 & 4.28 & 16.22 & 35.88 & 6.68 & 21.54 & 7.98 & 41.43 & 4.26 \\
\hline \multirow[t]{2}{*}{ PME/ f. } & $10 \mathrm{mg} \mathrm{Se} / \mathrm{L}$ & 87.78 & 5.15 & 17.31 & 40.44 & 7.52 & 23.11 & 8.58 & 43.04 & 3.91 \\
\hline & $20 \mathrm{mg} \mathrm{Se} / \mathrm{L}$ & 87.31 & 5.07 & 16.79 & 39.29 & 7.38 & 22.48 & 8.41 & 42.95 & 3.18 \\
\hline \multicolumn{2}{|c|}{ LSD at $5 \%$} & 1.02 & 0.12 & NS & 0.40 & 0.10 & 0.21 & NS & 0.19 & 0.161 \\
\hline
\end{tabular}

Table 7b. Effect of the interaction between foliar spray poultry manure extract and grains soaking at heading in 2016/ 2017 season.

\begin{tabular}{|c|c|c|c|c|c|c|c|c|c|c|}
\hline $\begin{array}{l}\text { Char. } \\
\text { PME }\end{array}$ & X Se & $\begin{array}{l}\text { Plant } \\
\text { height } \\
\text { (cm) }\end{array}$ & $\begin{array}{l}\text { No. of } \\
\text { tillers/ } \\
\text { plant }\end{array}$ & $\begin{array}{c}\text { No. of } \\
\text { leaves/ } \\
\text { plant }\end{array}$ & $\begin{array}{c}\text { Plant } \\
\text { fresh } \\
\text { weight } \\
\text { (g) }\end{array}$ & $\begin{array}{l}\text { Plant } \\
\text { dry } \\
\text { weight } \\
\text { (g) }\end{array}$ & $\begin{array}{c}\text { Flag leaf } \\
\text { area } \\
\left(\mathrm{cm}^{2}\right)\end{array}$ & $\begin{array}{c}\text { F.S.L.W. } \\
(\mathrm{mg} / \\
\left.\mathrm{cm}^{2}\right)\end{array}$ & $\begin{array}{c}\text { Total } \\
\text { chloroph } \\
\text { yll } \\
\text { (SPAD) }\end{array}$ & $\begin{array}{c}\text { Leaves } \\
\text { Proline } \\
\mu \mathrm{mol} / \mathrm{g} \\
\mathrm{FW}\end{array}$ \\
\hline \multicolumn{11}{|c|}{$2016 / 2017$} \\
\hline \multirow{5}{*}{ control } & control & 74.69 & 2.53 & 15.40 & 26.24 & 5.71 & 16.13 & 7.01 & 38.25 & 6.40 \\
\hline & $5 \mathrm{mg} \mathrm{Se} / \mathrm{L}$ & 77.78 & 2.86 & 15.89 & 29.98 & 6.05 & 17.91 & 7.42 & 39.09 & 5.69 \\
\hline & $10 \mathrm{mg} \mathrm{Se} / \mathrm{L}$ & 81.38 & 3.96 & 17.27 & 33.49 & 6.86 & 18.89 & 8.00 & 41.07 & 5.36 \\
\hline & $20 \mathrm{mg} \mathrm{Se} / \mathrm{L}$ & 80.93 & 3.76 & 16.79 & 32.02 & 6.75 & 18.25 & 7.84 & 40.74 & 4.68 \\
\hline & control & 77.22 & 3.18 & 15.60 & 29.88 & 6.10 & 18.15 & 7.20 & 38.55 & 5.88 \\
\hline $1 \mathrm{~m}^{3}$ & $5 \mathrm{mg} \mathrm{Se} / \mathrm{L}$ & 80.31 & 3.51 & 16.10 & 33.61 & 6.43 & 19.93 & 7.62 & 39.39 & 5.18 \\
\hline \multirow[t]{3}{*}{ PME/ f. } & $10 \mathrm{mg} \mathrm{Se} / \mathrm{L}$ & 83.91 & 4.61 & 17.48 & 37.12 & 7.24 & 20.91 & 8.20 & 41.37 & 4.84 \\
\hline & $20 \mathrm{mg} \mathrm{Se} / \mathrm{L}$ & 83.46 & 4.41 & 16.99 & 35.66 & 7.14 & 20.27 & 8.04 & 41.04 & 4.16 \\
\hline & control & 79.67 & 3.38 & 15.92 & 31.69 & 6.31 & 18.95 & 7.53 & 39.24 & 5.73 \\
\hline $2 \mathrm{~m}^{3}$ & $5 \mathrm{mg} \mathrm{Se} / \mathrm{L}$ & 82.76 & 3.71 & 16.41 & 35.43 & 6.65 & 20.73 & 7.95 & 40.08 & 5.03 \\
\hline \multirow[t]{3}{*}{ PME/ f. } & $10 \mathrm{mg} \mathrm{Se} / \mathrm{L}$ & 86.36 & 4.82 & 17.79 & 38.94 & 7.46 & 21.71 & 8.53 & 42.06 & 4.69 \\
\hline & $20 \mathrm{mg} \mathrm{Se} / \mathrm{L}$ & 85.91 & 4.62 & 17.31 & 37.47 & 7.35 & 21.07 & 8.37 & 41.73 & 4.01 \\
\hline & control & 82.75 & 4.11 & 16.46 & 34.17 & 6.84 & 21.32 & 8.12 & 40.91 & 5.49 \\
\hline $3 \mathrm{~m}^{3}$ & $5 \mathrm{mg} \mathrm{Se} / \mathrm{L}$ & 85.84 & 4.44 & 16.96 & 37.91 & 7.18 & 23.10 & 8.52 & 41.76 & 4.79 \\
\hline \multirow[t]{3}{*}{ PME/ f. } & $10 \mathrm{mg} \mathrm{Se} / \mathrm{L}$ & 89.44 & 5.55 & 18.34 & 41.42 & 7.99 & 24.08 & 9.16 & 43.73 & 4.45 \\
\hline & $20 \mathrm{mg} \mathrm{Se} / \mathrm{L}$ & 88.99 & 5.35 & 17.85 & 39.95 & 7.88 & 23.44 & 8.94 & 43.41 & 3.77 \\
\hline & control & 81.81 & 3.96 & 16.29 & 33.91 & 6.79 & 21.26 & 7.89 & 40.85 & 5.29 \\
\hline $4 \mathrm{~m}^{3}$ & $5 \mathrm{mg} \mathrm{Se} / \mathrm{L}$ & 85.74 & 4.29 & 16.78 & 37.55 & 7.10 & 23.04 & 8.39 & 41.67 & 4.59 \\
\hline \multirow[t]{2}{*}{ PME/ f. } & $10 \mathrm{mg} \mathrm{Se} / \mathrm{L}$ & 89.11 & 5.46 & 18.16 & 41.31 & 7.93 & 24.02 & 8.88 & 43.68 & 4.25 \\
\hline & $20 \mathrm{mg} \mathrm{Se} / \mathrm{L}$ & 88.34 & 5.27 & 17.68 & 39.84 & 7.81 & 23.38 & 8.72 & 43.38 & 3.57 \\
\hline \multicolumn{2}{|c|}{ LSD at $5 \%$} & 1.10 & 0.18 & NS & 1.05 & 0.08 & 0.29 & NS & 0.13 & 0.10 \\
\hline
\end{tabular}

Yield and its components:

Data reported in Table ( $8 \mathrm{a}$ and $\mathrm{b}$ ) indicated that effect of the interaction between spraying of PME and soaking wheat grains by Se levels had a significant effect on yield and its components i.e. number of spikes/ $\mathrm{m}^{2}$, spike length $(\mathrm{cm})$, spikes weight $(\mathrm{g})$, number of spikelets/ spike, number of grains/ spike, 1000-grain weight (g), Grain yield $\mathrm{kg} /$ fed., Straw yield $\mathrm{kg} /$ fed., harvest Index (\%) and crop Index (\%) were obtained at in both seasons. The maximum increments for yield and its components were obtained by spraying plants of wheat by $3 \mathrm{~m}^{3} \mathrm{PME} /$ feddan with soaking wheat grains 
by $10 \mathrm{mg} \mathrm{Se} / 1$ in both seasons. The lowest values were recorded with control treatments of PME and $\mathrm{Se}$ (without PME spraying and soaking grains by Se) in the two growing seasons.

It could be concluded that the spraying of wheat plants by $3 \mathrm{~m} 3$ poultry manure extract/ fed. Is sufficient to reach the highest productivity of wheat plants whereas, it was observed during the growing seasons yellowing some leaves of plant after spraying process at the highest level of PME, this is evidence that spraying with $4 \mathrm{~m} 3 /$ fed. is reached to damage of plants. On the other hand, soaking of wheat grains in $10 \mathrm{mg} \mathrm{Se} / 1$ is sufficient to obtain the best effect on yield and its components. The best results were obtained with this level and the increase of it was cannot give significant increasing.

Table 8a. Effect of the interaction between foliar spray poultry manure extract and grains soaking on wheat yield and its components 2015/ 2016 season.

\begin{tabular}{|c|c|c|c|c|c|c|c|c|c|c|c|}
\hline $\begin{array}{l}\text { Char. } \\
\text { PME }\end{array}$ & $\mathrm{X}$ Se & $\begin{array}{c}\text { No. of } \\
\text { spikes } \\
/ \mathrm{m}^{2}\end{array}$ & $\begin{array}{l}\text { Spike } \\
\text { length } \\
(\mathrm{cm})\end{array}$ & $\begin{array}{c}\text { Spike } \\
\text { weight } \\
\text { (g) }\end{array}$ & $\begin{array}{c}\text { No. of } \\
\text { spikelets } \\
\text { /spike }\end{array}$ & $\begin{array}{l}\text { No. of } \\
\text { grains } \\
\text { /spike }\end{array}$ & $\begin{array}{c}\text { 1000-grain } \\
\text { weight(g) }\end{array}$ & $\begin{array}{c}\text { Grain } \\
\text { yield } \\
\text { (kg/fed.) }\end{array}$ & $\begin{array}{c}\text { Straw } \\
\text { yield } \\
\text { (kg/fed.) }\end{array}$ & $\begin{array}{l}\text { Harvest } \\
\text { index \% i }\end{array}$ & $\begin{array}{c}\text { Crop } \\
\text { ndex \% }\end{array}$ \\
\hline \multirow{5}{*}{ control } & & & & & $2015 / 2$ & 2016 & & & & & \\
\hline & (control) & 336.3 & 7.63 & 2.05 & 15.18 & 33.41 & 34.73 & 1222 & 1605 & 36.78 & 59.42 \\
\hline & $5 \mathrm{mg} \mathrm{Se} / \mathrm{L}$ & 343.1 & 8.19 & 2.24 & 15.84 & 35.63 & & 1416 & 2008 & & 60.46 \\
\hline & $10 \mathrm{mg} \mathrm{Se} / \mathrm{L}$ & 347.4 & 9.10 & 2.64 & 16.86 & 37.90 & 38.55 & 1599 & 2282 & 38.34 & 60.97 \\
\hline & $20 \mathrm{mg} \mathrm{Se} / \mathrm{L}$ & 345.7 & 8.53 & 2.54 & 16.38 & 37.16 & 38.28 & 1572 & 2238 & & 60.78 \\
\hline & (control) & 346.7 & 8.69 & 2.26 & 15.62 & 34.65 & 87 & 1360 & 1711 & 27 & 60.76 \\
\hline $1 \mathrm{~m}^{3}$ & $5 \mathrm{mg} \mathrm{Se} / \mathrm{L}$ & 353.5 & 9.25 & 2.44 & 16.28 & 36.88 & 3 & 1555 & 2114 & 3 & 61.81 \\
\hline \multirow[t]{3}{*}{ PME/ f. } & $10 \mathrm{mg} \mathrm{Se} / \mathrm{L}$ & 357.8 & 10.16 & 2.84 & 17.3 & 39.15 & 3 & 1738 & 2388 & 3 & 62.32 \\
\hline & $20 \mathrm{mg}$ & 356.1 & 9.59 & 2.74 & 16.82 & 38.41 & & 1710 & 2344 & & \\
\hline & (contr & 353.7 & 9.11 & 2.45 & 16.02 & 35.61 & & 1458 & 1816 & 37.52 & 61.63 \\
\hline $2 \mathrm{~m}^{3}$ & $5 \mathrm{mg} \mathrm{Se} / \mathrm{L}$ & 360.5 & 9.67 & 2.64 & 16.67 & 37.84 & 3 & 1652 & 2219 & & 62.68 \\
\hline \multirow[t]{3}{*}{ PME/ f. } & $10 \mathrm{mg} \mathrm{Se} / \mathrm{L}$ & 364.7 & 10.58 & 3.04 & 17.69 & 40.11 & 40 & 1835 & 2493 & & 63.19 \\
\hline & $20 \mathrm{mg} \mathrm{Se} / \mathrm{L}$ & 363.1 & 10.02 & 2.94 & 17.21 & 39.37 & & 1808 & 2448 & & 63.00 \\
\hline & (contrc & 360.3 & 9.63 & 2.61 & 16.53 & 37.37 & 37.56 & 1570 & 1908 & 37.79 & 62.66 \\
\hline $3 \mathrm{~m}^{3}$ & $5 \mathrm{mg} \mathrm{Se} / \mathrm{L}$ & 367.1 & 10.19 & 2.79 & 17.18 & 39.59 & 39.22 & 1764 & 2311 & 38.46 & 63.71 \\
\hline \multirow[t]{3}{*}{ PME/ f. } & $10 \mathrm{mg} \mathrm{Se} / \mathrm{L}$ & 371.3 & 11.10 & 3.19 & 18.20 & 41.86 & 41.38 & 1947 & 2585 & & 64.22 \\
\hline & $20 \mathrm{mg} \mathrm{Se} / \mathrm{L}$ & 369.7 & 10.53 & 3.09 & 17.72 & 41.12 & & 1920 & 2540 & & 64.03 \\
\hline & (contro & 363.6 & 9.72 & 2.67 & 16.64 & 37.58 & 2 & 1602 & 1962 & & 62.95 \\
\hline $4 \mathrm{~m}^{3}$ & $5 \mathrm{mg} \mathrm{Se} / \mathrm{L}$ & 370.4 & 10.28 & 2.85 & 17.29 & 39.80 & & 1797 & 2365 & & 63.99 \\
\hline \multirow[t]{2}{*}{ PME/ f. } & $10 \mathrm{mg} \mathrm{Se} / \mathrm{L}$ & 374.6 & 11.19 & 3.25 & 18.31 & 42.07 & 41 & 1980 & 2639 & 44 & 64.50 \\
\hline & 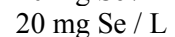 & 373.0 & 10.62 & 3.15 & 17.83 & 41.33 & & 1952 & 2595 & & 64.31 \\
\hline \multicolumn{2}{|c|}{ LSD at $5 \%$} & 1.26 & 0.08 & 0.05 & 0.10 & 0.13 & 0.21 & 30 & 0.52 & 0.08 & 0.22 \\
\hline
\end{tabular}

Table 8b. Effect of the interaction between foliar spray poultry manure extract and grains soaking on wheat yield and its components 2016/ 2017 season.

\begin{tabular}{|c|c|c|c|c|c|c|c|c|c|c|c|}
\hline PME & $\begin{array}{l}\text { X Shar. } \\
\text { Se }\end{array}$ & $\begin{array}{l}\text { No. of } \\
\text { spikes } \\
/ \mathrm{m}^{2}\end{array}$ & $\begin{array}{c}\text { Spike } \\
\text { length } \\
(\mathrm{cm})\end{array}$ & $\begin{array}{c}\text { Spike } \\
\text { weight } \\
\text { (g) }\end{array}$ & $\begin{array}{c}\text { No. of } \\
\text { spikelets } \\
\text { /spike } \\
\text { 2016/ } 2 \\
\end{array}$ & $\begin{array}{l}\text { No. of } \\
\text { grains } \\
\text { /spike } \\
2017 \\
\end{array}$ & $\begin{array}{c}1000- \\
\text { grain } \\
\text { weight }(g)\end{array}$ & $\begin{array}{c}\text { Grain } \\
\text { yield } \\
\text { (kg/fed.) }\end{array}$ & $\begin{array}{c}\text { Straw } \\
\text { yield } \\
\text { (kg/fed.) }\end{array}$ & $\underset{\substack{\text { Harvest } \\
\text { index }}}{\text { Harve }}$ & $\begin{array}{c}\text { Crop } \\
\text { index } \\
\%\end{array}$ \\
\hline \multirow{4}{*}{ control } & (control) & 343.8 & 7.84 & 2.11 & 15.57 & 34.62 & 35.22 & 1255 & 2057 & 37.24 & 59.99 \\
\hline & $5 \mathrm{mg} \mathrm{Se} / \mathrm{L}$ & 351.6 & 8.46 & 2.33 & 16.10 & 36.95 & 37.04 & 1452 & 2171 & 37.95 & 60.92 \\
\hline & $10 \mathrm{mg} \mathrm{Se} / \mathrm{L}$ & 357.4 & 9.28 & 2.69 & 17.18 & 39.03 & 39.37 & 1649 & 2328 & 38.88 & 61.82 \\
\hline & $20 \mathrm{mg} \mathrm{Se} / \mathrm{L}$ & 355.3 & 8.99 & 2.55 & 17.02 & 38.21 & 39.02 & 1611 & 2298 & 38.66 & 61.49 \\
\hline & (control) & 352.6 & 8.79 & 2.36 & 15.97 & 35.80 & 36.61 & 1385 & 2151 & 37.65 & 61.75 \\
\hline $1 \mathrm{~m}^{3}$ & $5 \mathrm{mg} \mathrm{Se} / \mathrm{L}$ & 360.4 & 9.41 & 2.58 & 16.50 & 38.13 & 38.43 & 1582 & 2264 & 38.35 & 62.68 \\
\hline \multirow[t]{3}{*}{ PME/ f. } & $10 \mathrm{mg} \mathrm{Se} / \mathrm{L}$ & 366.2 & 10.23 & 2.94 & 17.58 & 40.21 & 40.76 & 1779 & 2421 & 39.28 & 63.58 \\
\hline & $20 \mathrm{mg} \mathrm{Se} / \mathrm{L}$ & 364.1 & 9.94 & 2.80 & 17.42 & 39.39 & 40.41 & 1741 & 2391 & 39.07 & 63.25 \\
\hline & (control) & 358.9 & 9.38 & 2.49 & 16.39 & 37.24 & 37.36 & 1501 & 2274 & 38.09 & 62.16 \\
\hline $2 \mathrm{~m}^{3}$ & $5 \mathrm{mg} \mathrm{Se} / \mathrm{L}$ & 366.8 & 10.00 & 2.71 & 16.92 & 39.56 & 39.18 & 1698 & 2387 & 38.80 & 63.09 \\
\hline \multirow[t]{2}{*}{ PME/ f. } & $10 \mathrm{mg} \mathrm{Se} / \mathrm{L}$ & 372.5 & 10.82 & 3.08 & 18.00 & 41.65 & 41.51 & 1895 & 2544 & 39.73 & 63.99 \\
\hline & $20 \mathrm{mg} \mathrm{Se} / \mathrm{L}$ & 370.5 & 10.53 & 2.94 & 17.84 & 40.83 & 41.17 & 1857 & 2514 & 39.51 & 63.66 \\
\hline & (control) & 364.2 & 9.82 & 2.68 & 16.99 & 38.35 & 38.21 & 1614 & 2380 & 38.42 & 63.30 \\
\hline $3 \mathrm{~m}^{3}$ & $5 \mathrm{mg} \mathrm{Se} / \mathrm{L}$ & 372.1 & 10.44 & 2.90 & 17.52 & 40.67 & 40.03 & 1811 & 2493 & 39.13 & 64.24 \\
\hline \multirow[t]{3}{*}{ PME/ f. } & $10 \mathrm{mg} \mathrm{Se} / \mathrm{L}$ & 377.8 & 11.26 & 3.27 & 18.60 & 42.76 & 42.36 & 2008 & 2650 & 40.06 & 65.13 \\
\hline & $20 \mathrm{mg} \mathrm{Se} / \mathrm{L}$ & 375.8 & 10.97 & 3.13 & 18.44 & 41.94 & 42.01 & 1970 & 2620 & 39.84 & 64.80 \\
\hline & (control) & & 9.97 & & 17.18 & 38.79 & 38.58 & 1632 & 2415 & 38.54 & 63.55 \\
\hline $4 \mathrm{~m}^{3}$ & $5 \mathrm{mg} \mathrm{Se} / \mathrm{L}$ & 375.7 & 10.59 & 2.95 & 17.72 & 41.12 & 40.40 & 1829 & 2529 & 39.25 & 64.49 \\
\hline \multirow{2}{*}{ PME/ f. } & $10 \mathrm{mg} \mathrm{Se} / \mathrm{L}$ & 381.4 & 11.41 & 3.32 & 18.80 & 43.20 & 42.73 & 2026 & 2686 & 40.18 & 65.38 \\
\hline & $20 \mathrm{mg} \mathrm{Se} / \mathrm{L}$ & 379.4 & 11.12 & 3.18 & 18.64 & 42.38 & 42.38 & 1988 & 2656 & 39.96 & 65.05 \\
\hline \multicolumn{2}{|c|}{ LSD at $5 \%$} & 1.14 & 0.11 & 0.04 & 0.17 & 0.40 & 0.35 & 16 & 34 & 0.11 & 0.25 \\
\hline
\end{tabular}

Chemical composition:

Data in Table (9) revealed that effect of the interaction between spraying of PME and soaking wheat grains by Se levels had a significant effect on all studied chemical composition except, potassium percentages in grains were insignificant in the two growing seasons. The highest values of grains content of chemical composition studied were produced by using $3 \mathrm{~m}^{3} /$ feddan of PME and soaking of grains with $10 \mathrm{mg} \mathrm{Se} / 1$ in the first and second seasons. 
Table 9. Effect of the interaction between foliar spray poultry manure extract and grains soaking on chemical composition of wheat grains $2015 / 2016$ and $2016 / 2017$ seasons .

\begin{tabular}{|c|c|c|c|c|c|c|c|c|c|c|c|c|c|}
\hline \multirow{3}{*}{\multicolumn{2}{|c|}{ Char. }} & \multicolumn{2}{|c|}{ N\% } & \multicolumn{2}{|c|}{ P \% } & \multicolumn{2}{|c|}{ K\% } & \multicolumn{2}{|c|}{ Se \% } & \multicolumn{2}{|c|}{ Protein \% } & \multicolumn{2}{|c|}{ Total Carboh.\% } \\
\hline & & $\overline{2015}$ & $2016 /$ & 2015 & 2016 & 2015 & 2016 & 2015 & 2016 & $2015 /$ & 2016/ & 2015 & 2016 \\
\hline & & 2016 & 2017 & 2016 & 2017 & 2016 & 2017 & 2016 & 2017 & 2016 & 2017 & 2016 & 2017 \\
\hline \multirow{4}{*}{ control } & control & 1.41 & 1.42 & 0.18 & 0.19 & 0.27 & 0.27 & 0.11 & 0.12 & 8.28 & 8.34 & 57.31 & 57.78 \\
\hline & $5 \mathrm{mg} \mathrm{Se} / \mathrm{L}$ & 1.57 & 1.62 & 0.19 & 0.20 & 0.27 & 0.28 & 0.23 & 0.24 & 9.15 & 9.35 & 58.32 & 59.40 \\
\hline & $10 \mathrm{mg} \mathrm{Se} / \mathrm{L}$ & 1.80 & 1.83 & 0.22 & 0.22 & 0.28 & 0.29 & 0.48 & 0.49 & 10.38 & 10.64 & 59.89 & 60.44 \\
\hline & $20 \mathrm{mg} \mathrm{Se} / \mathrm{L}$ & 1.70 & 1.76 & 0.21 & 0.22 & 0.28 & 0.28 & 0.35 & 0.37 & 9.99 & 10.09 & 59.25 & 60.14 \\
\hline & control & 1.52 & 1.55 & 0.19 & 0.20 & 0.27 & 0.28 & 0.15 & 0.16 & 9.31 & 9.54 & 58.66 & 59.52 \\
\hline $1 \mathrm{~m}^{3}$ & $5 \mathrm{mg} \mathrm{Se} / \mathrm{L}$ & 1.69 & 1.74 & 0.20 & 0.21 & 0.28 & 0.28 & 0.27 & 0.28 & 10.18 & 10.54 & 59.68 & 61.14 \\
\hline \multirow{3}{*}{ PME/ f. } & $10 \mathrm{mg} \mathrm{Se} / \mathrm{L}$ & 1.91 & 1.95 & 0.23 & 0.23 & 0.29 & 0.29 & 0.52 & 0.54 & 11.41 & 11.83 & 61.24 & 62.18 \\
\hline & $20 \mathrm{mg} \mathrm{Se} / \mathrm{L}$ & 1.81 & 1.88 & 0.22 & 0.23 & 0.28 & 0.29 & 0.39 & 0.41 & 11.02 & 11.28 & 60.60 & 61.88 \\
\hline & control & 1.67 & 1.71 & 0.20 & 0.21 & 0.28 & 0.28 & 0.19 & 0.19 & 9.99 & 10.22 & 59.73 & 60.58 \\
\hline $\mathrm{m}^{3}$ & $5 \mathrm{mg} \mathrm{Se} / \mathrm{L}$ & 1.84 & 1.91 & 0.22 & 0.22 & 0.28 & 0.29 & 0.31 & 0.31 & 10.86 & 11.23 & 60.74 & 62.21 \\
\hline \multirow[t]{3}{*}{ PME/ f. } & $10 \mathrm{mg} \mathrm{Se} / \mathrm{L}$ & 2.06 & 2.12 & 0.24 & 0.25 & 0.29 & 0.30 & 0.56 & 0.57 & 12.09 & 12.52 & 62.31 & 63.24 \\
\hline & $20 \mathrm{mg} \mathrm{Se} / \mathrm{L}$ & 1.96 & 2.05 & 0.23 & 0.24 & 0.29 & 0.29 & 0.42 & 0.44 & 11.70 & 11.97 & 61.67 & 62.94 \\
\hline & control & & 1.81 & 0.21 & 0.22 & 0.28 & 0.29 & 0.21 & 0.22 & 10.13 & 10.68 & 61.07 & 61.34 \\
\hline $3 \mathrm{~m}^{3}$ & $5 \mathrm{mg} \mathrm{Se} / \mathrm{L}$ & 1.94 & 2.00 & 0.23 & 0.23 & 0.29 & 0.30 & 0.33 & 0.34 & 11.00 & 11.68 & 62.09 & 62.97 \\
\hline \multirow[t]{3}{*}{ PME/ f. } & $10 \mathrm{mg} \mathrm{Se} / \mathrm{L}$ & 2.26 & 2.30 & 0.26 & 0.26 & 0.31 & 0.31 & 0.61 & 0.62 & 12.91 & 13.26 & 64.29 & 64.97 \\
\hline & $20 \mathrm{n}$ & 2.07 & 2.14 & 0.24 & 0.25 & 0.30 & 0.30 & 0.45 & 0.47 & 11.84 & 12.42 & 63.01 & 63.70 \\
\hline & control & 1.87 & 1.89 & 0.22 & 0.23 & 0.29 & 0.30 & 0.24 & 0.24 & 10.81 & 10.96 & 61.71 & 62.31 \\
\hline $4 \mathrm{~m}^{3}$ & $5 \mathrm{mg} \mathrm{Se} / \mathrm{L}$ & 2.03 & 2.09 & 0.23 & 0.24 & 0.30 & 0.30 & 0.36 & 0.37 & & 11.97 & 62.73 & 63.93 \\
\hline \multirow{3}{*}{$\mathrm{PME} / \mathrm{f}$. } & $10 \mathrm{mg} \mathrm{Se} / \mathrm{L}$ & 2.17 & 2.21 & 0.25 & 0.26 & 0.30 & 0.30 & 0.58 & 0. & 12 & 12.97 & 63.65 & 64.00 \\
\hline & $20 \mathrm{mg} \mathrm{Se} / \mathrm{L}$ & 2.16 & 2.23 & 0.25 & 0.26 & 0.3 & 0.31 & 0.47 & 0.49 & 12.52 & 12.71 & 63.65 & 64.67 \\
\hline & LSD at $5 \%$ & 0.05 & 0.04 & 0.02 & 0.01 & NS & NS & 0.04 & 0.03 & 0.07 & 0.08 & 0.11 & 0.10 \\
\hline
\end{tabular}

\section{REFERENCES}

BadrELdin A. M., F. E. Ahmed, H. I. Dessougi. 2016. Interactive Effect of chicken manure with nitrogen fertilizer and watering regimes on yield and its components of bread wheat, Sch J Agric Vet Sci., 3(3):234-237.

Bill K., C. Zein, T. Albert and C. Watts. 2017."Influence of selenium application methods.Agron.J.79:563-570.

Chen C.C. and J. M. Sung. 2001. Priming bitter gourd seeds with selenium solution enhancesgerminability and antioxidative responses under sub-optimal temperature. Physiol. Plant 111:9-16.

Din R., G. Subhani, N. Ahmad, N. Hussain and M. Rhman 2010. Effect of temperature on development and grain formation in spring wheat.Pakistan Journal of Botany 42, 899- 906.

FAO. 2017. Food and Agricultural Organization. www. Fao.Org. (C.F. Computer research).

Feng R., C. Wei and S. Tu. 2013. The roles of selenium in protecting plants against abiotic stresses. Environ. Exp. Bot. 87: 58-68.

Gomez K. A. and A. A. Gomez. 1984. Statistical procedures in agricultural research. New York, Chichester, Wiley $1984,{ }^{2}$ nd edition, paperback. pp 680.

Gowda K.A, N. K. Biradarpatil, R. N. Patil, S. A. Awaknavar and R. Hunje. 2008. Effect of organic manures on growth, seed yield and quality of wheat. Karnataka J. Agric. Sci., 21(3): 366-368.

Hartikainen H., T. Xue and V. Piironen .2000.Selenium as an antioxidant and pro-oxidant in ryegrass. Plant Soil 225:193-200.

Ibrahim M.S. 2008. Effect of irrigation regime, organic and inorganic $\mathrm{N}$ fertilizers on wheat yield and its component and residual soil nitrate. J Appl. Sci. Res., 4: 1008-1016.

John M. K. 1970. Colorimetric determination of phosphorus in soil and plant materials with ascorbic acid. Soil Sci. 109: 214.
Johnson C.M. and A. Ulrich. 1959. Analytical methods for use in plant analysis. U.S. Dept. Agric., Calif. Univ., Agric. Inform. Bull., 766.

Kishor P.B. S. Sangama, R.N. Amrutha, P.S. Laxmi, K.R. Naidu, K.S. Rao .2005. Regulation of proline biosynthesis degradation, uptake and transport in higher plants: its implications in plant growth and abiotic stress tolerance. Curr. Sci. 88:424-438.

Luoma P., S. Nayha, K. Sikkila and J. Hassi.1995.High serum alpha-tocopherol, albumin, selenium and cholesterol, and low mortality from coronary heart disease in northern Finland. J Int. Med 237:49-54.

Martinez A., B. Martinez, A. Bermejo, F. Legaz and A. Quinones. 2016. Liquid organic fertilizers for sustainable agriculture: Nutrient uptake of organic versus mineral fertilizers in wheat. PLoS ONE, 11, e0161619.

Mona, I. Nossier, S. Gawish, T. Taha and M. Mubarak. 2017. Response of wheat plants to application of selenium and humic acid under salt stress conditions. Egypt. J. Soil Sci., 57 (2) 175 - 187.

Montogomery R. 1961. Further studies of the phenol sulphoric acid reagent for carbohydrate. Biochem. Biophus. Acta, 48:59.

Moussa M., A. Khan and K. Abasi. 2006. Production of organic wheat crop. Crop Res. Hisar. 28:698705.

Nawaz F, Ashraf, R. Ahmad and E. Waraich. 2015. Selenium seed priming induced growth and biochemical changes in wheat under water deficit conditions. Biol. Trace Elem. Res., 151: 284-293.

Niggli U. 2007. Wheat quality in organic and conventional farming: results of a 21 year field experiment. J. Sci. Food Agric. 87: 1826-1835.

Peach K. and M.V. Tracey. 1956. Modern methods of plant analysis. Vol. 1.Springer Verlag. Berlin, 4, 643. 
Sivritepe H., N. Sivritepe, A, Eris and E. Turhan. 2005. The effects of $\mathrm{NaCl}$ pre-treatment on salt tolerance of melons grown under longterm salinity. SciHort 106:568-581.

Slafer G.A. and E.H. Satorre.1999. An introduction to the physiological-ecological analysis of wheat yield. In: Wheat:Ecology and Physiology of Yield Determination.The Haworth Press,New York.pp.3-12.

Smith D. G. M. Poulsen and C.A. Raguse. 1964. Extraction of total available carbohydrates from grass and legume tissues, Plant physiol., 39: 960.

Sujin R.W. 2004. Stress-inducible synthesis of proline in transgenic rice confers faster growth under stress conditions than that with constitutive synthesis. Plant Sci. 166:941-948.

Tadina H., M. Germ, I. Kreft, B. Breznik and A. Gaberscik. 2007. Effects of water deficit and selenium on common buck wheat Plants. Photosynth. 45: 472-476.

Teimouri S., J. Hasanpour and A. Tajali. 2013. Effect of selenium spraying on yield and growth indices of wheat (Triticumaestivum L.) under drought stress condition. Intern J. Adv. Biol. Biomed Res., 2: 2091-2103.
Wahid A. and A. Shabbir.2005. Induction of heat stress tolerance in barley seedlings by pre-sowing seed treatment with glycinebetaine. Plant Growth Regul. 46:133-141.

Wahid A., S. Gelani, M. Ashraf and M. Foolad. 2007. Heat tolerance in plants: an overview. Environmental and Experimental Botany 61, 199-223.

Yao X., C. Jianzhou , H. Xueli, L. Binbin, Y. Jingmin, Y. Zhaowei. 2013. Effect of selenium on agronomical characters of winter wheat exposed to enhanced ultraviolet-B. Ecotox Environ Safety. 92: 320-326.

Yao X., J. Z. Chu and G. Y. Wang. 2009. Effects of drought stress and selenium supply on growth and physiological characteristics of wheat seedlings. Acta Physiol. Plant. 31: 1031-1036.

Younes C., F.Mohyedi, M.Kalhor. 2016. Effect of organic and chemical fertilizers on yield components of common wheat (Triticumaestivum L.). IIOABJ | Vol. 7 ( 8) 2-86

$$
\begin{aligned}
& \text { تأثير السيلينيوم والرش بمستخلص السماد العضوي على إنتاجية وجودة القمح تحت ظروف الوادي الجديا }
\end{aligned}
$$

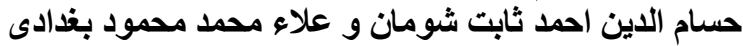

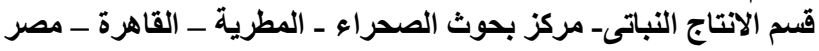

أجريت تجربتان حقليتان بمحطة بحوثالخارجة التابعة لمركز بحوث الصحر اء بمحافظة الو ادي الجديد خلال موسمين زر اعيين

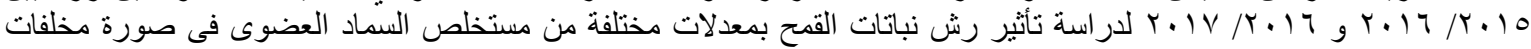

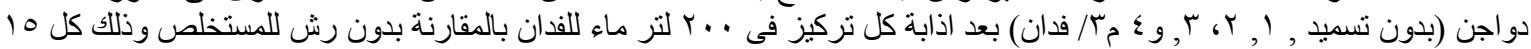

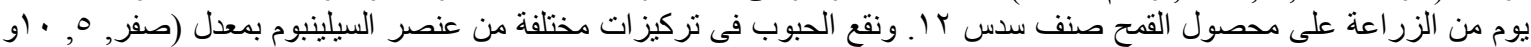

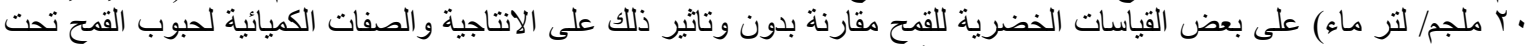

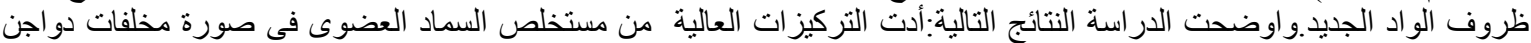

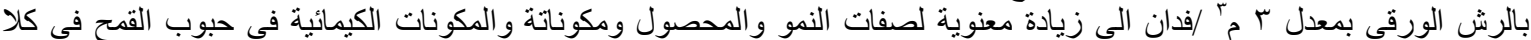

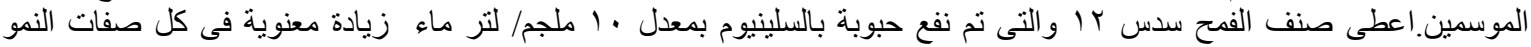

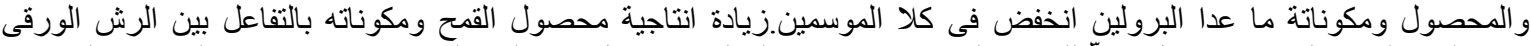

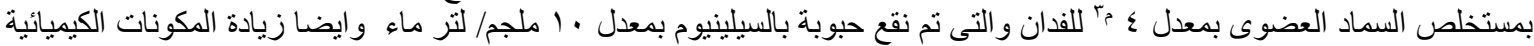

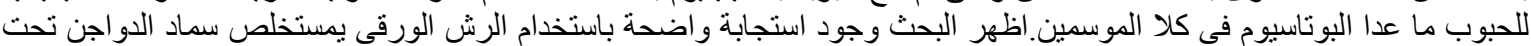

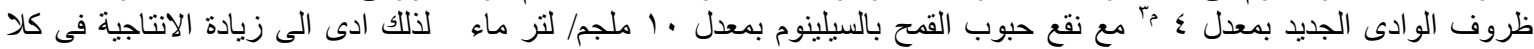

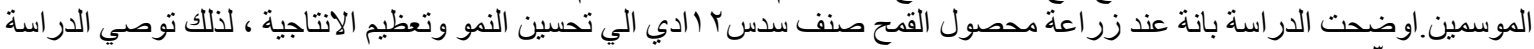

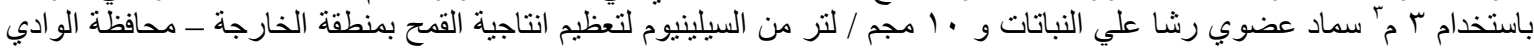

